\title{
Use of Coffee Capsules as Support Material in Upflow Anaerobic Fixed Bed Reactors
}

\author{
Gabriela Rezende de Souza ${ }^{{ }^{*}}$ \\ https://orcid.org/0000-0001-5915-7529 \\ Luiz Fernando Coutinho de Oliveira ${ }^{1}$ \\ https://orcid.org/0000-0001-5260-3258 \\ Italoema Pinheiro Bello ${ }^{1}$ \\ https://orcid.org/0000-0001-6891-240X
}

Luciene Alves Batista Siniscalchi ${ }^{1}$

https://orcid.org/0000-0001-7892-0112

\section{Ronaldo Fia ${ }^{1}$}

https://orcid.org/0000-0001-6824-0869

\section{Rômulo Marçal Gandia ${ }^{2}$}

https://orcid.org/0000-0002-7786-1525

${ }^{1}$ Federal University of Lavras, Department of Water Resources and Sanitation, Lavras, MG, Brazil;

${ }^{21}$ Federal University of Lavras, Department of Agricultural Engineering, Lavras, MG, Brazil;

Received: 2018.09.17; Accepted: 2019.03.18.

* Correspondence: rezendesgabriela@gmail.com; Tel.: +55-35-999018076 (G.R.S)

\section{HIGHLIGHTS}

- Reusing coffee capsules as an alternative to theirs disposal.

- Low cost wastewater treatment.

- Ally solutions for the treatment of liquid and solid waste.

Abstract: The aim of this work is to evaluate the performance of upflow anaerobic fixed
bed reactors filled with espresso coffee capsules to treat sanitary sewage. Three reactors
(R1, R2 and R3) were constructed in blue PVC pipes measuring $30 \mathrm{~cm}$ height and $150 \mathrm{~mm}$
diameter and filled with coffee capsules made of aluminum and plastic. The sewage from
the pre-treatment phase of the wastewater treatment plant of the Federal University of
Lavras fed the system. Temperature, pH, alkalinity and volatile acids concentration, COD,
TS, TVS and TSS of the influent and effluent were analyzed to evaluate the reactors 
performances. Statistics tests were run in the software Statistica 10. Changes occurred in the organic loading rates caused two different operating phases, one at an OLR of $2.1 \mathrm{~kg}$ COD m-3d-1 and another at $4.0 \mathrm{~kg} \mathrm{COD} \mathrm{m-3d-1.} \mathrm{The} \mathrm{average} \mathrm{temperature} \mathrm{during} \mathrm{the}$ monitoring period was $18^{\circ} \mathrm{C}$. In spite of the operating conditions variations, the reactors showed satisfactory performances, presenting COD efficiency removals up to $80 \%$ in both phases. The capsules characteristics were similar to other materials used as support. Hence, it is possible to utilize coffee capsules as support material in anaerobic reactors, providing satisfactory pollutants removal efficiencies.

Keywords: anaerobic filter; biomass; immobilization; support material; domestic sewage.

\section{INTRODUCTION}

The quality of water resources is still a serious problem faced in Brazil. According to the National Water Agency, $22 \%$ of the rivers located near urban areas present poor or terrible water quality [1]. The discharge of domestic and industrial liquid effluents without any treatment is the main cause of surface water pollution. In Brazil, less than half of the sewage is collected and treated and $70 \%$ of the municipalities do not have wastewater treatment plants [2].

Anaerobic wastewater treatment is widely used due to several favorable aspects when compared to aerobic degradation. The anaerobic filter, developed by Young and McCarty [3], was the first anaerobic fixed bed reactor proposed in the literature, in which occurs microbial attachment in a support material and in the interstitial spaces of the bed. This arrangement promotes the biomass retention inside the reactor and allows adaptation conditions to organisms with slower growth rates.

A great number of support materials have been used to immobilize biomass in aerobic and anaerobic reactors, in order to improve treatment efficiency and the application of economical and viable supports [4-9]. The support materials applied to effluent treatment are generally inert, such as sand, gravel, ceramics, plastic rings and sponges. However, some research has applied non-inert supports for microorganism attachment, such as bamboo and oyster shells [10-15].

The development and improvement of waste treatment technologies, both solid and liquid, are essential to minimize the environmental impacts caused by human activities. In addition, pursuing economic alternatives to waste treatment is fundamental to ensure sanitation to all people and improve the quality of natural resources. In this context, the use of espresso coffee capsules as support material in the wastewater treatment arises.

In recent years, the consumption of coffee capsules has increased significantly, which has led to numerous discussions regarding the waste generation. This problem is mainly caused due to the difficulty of recycling these materials. Only in 2014, Brazil imported 440 million coffee capsules [16]. According to Silva et al. [17], among the five brands of singledose espresso most sold worldwide, three of them use plastic capsules, one uses aluminum capsules and one uses paper pods. Paper pods are an alternative to reduce waste generation, since the filter is biodegradable. Aluminum capsules can be effortlessly recycled and the production of biodegradable capsules is already a reality, such as those produced from bamboo resin and corn base. Nevertheless the concern about this residue is still important [18].

Hence the objective of this work was to assess the performance of upflow anaerobic fixed bed reactors filled with coffee capsules to treat sanitary sewage. This work also aimed to offer an adequate destination and value aggregation alternative to the residue, as well as new alternatives of sewage treatment.

\section{MATERIAL AND METHODS}


The experimental system was located in the wastewater treatment plant of the Federal University of Lavras (WWTP-UFLA). Three upflow anaerobic fixed bed reactors (R1, R2 and R3) were constructed in PVC pipes, each with a total volume of $4.4 \mathrm{~L}$, to treat the sewage from the campus. The influent of the system was collected past the pre-treatment stage of the WWTP-UFLA, which is composed of the grid and grease trap. The experiment was performed between fall and winter seasons, at an $18^{\circ} \mathrm{C}$ average temperature, as the reactors were submitted to the ambient temperature fluctuations.

The reactors measured $150 \mathrm{~mm}$ diameter and $300 \mathrm{~mm}$ height, equipped with PVC caps in the bottom and top for sealing. The inlet sewage was flowed by PVC pipes of $20 \mathrm{~mm}$ diameter in the bottom of the reactors and a Tee fitting to promote a better distribution of the liquid. Peristaltic pumps collected the effluent with a flow ranging from 0.004 to $0.032 \mathrm{~L}$ min1 , resulting in a hydraulic retention time (HRT) of 2.2 to 16.9 hours, which was calculated considering the volume of empty spaces in the reactors.

Coffee capsules, sometimes named as coffee pods, and its components were used inside the reactors as support material to biomass immobilization. The capsules were collected from users of single-dose coffee machines, obtaining aluminum and plastic capsules. They were cleaned to remove the coffee residue and washed with running water. The capsules seals were removed as well.

The reactor R1 was filled with 170 aluminum capsules smashed by hand; R2 filled with 40 plastic capsules smashed by hand and 40 plastic discs, which is a capsule component; and R3 filled with 40 plastic capsules and 40 discs. The fixed bed was established at $25 \mathrm{~cm}$ height, utilizing plastic grids to avoid the material fluctuation. Figure 1 shows a schematic drawing of the experimental reactors and system view. To perform the system start-up, the reactors were inoculated with $500 \mathrm{~mL}$ of granulated sludge from an UASB of the university plant. Table 1 shows the support materials characteristics in each reactor.

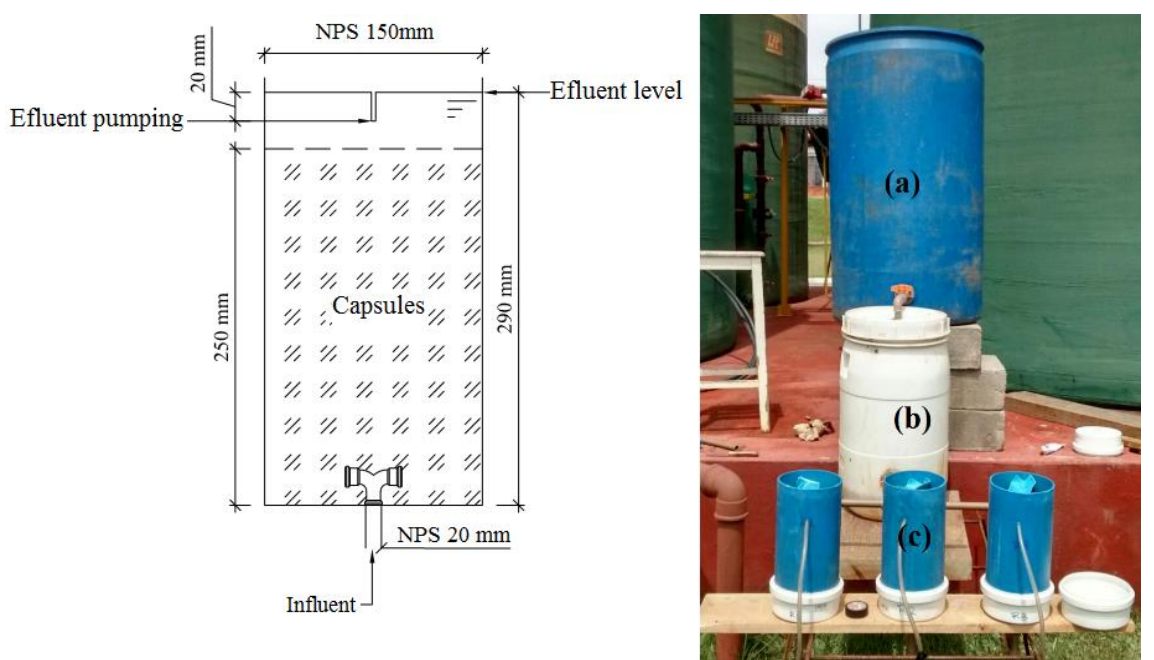

Figure 1. Reactor schematic drawing and operating system design: (a) sewage reservoir, (b) level reservoir and (c) PVC reactors.

Table 1. Support materials characteristics in the reactors.

\begin{tabular}{cccc}
\hline Characteristics & $\mathbf{R 1}$ & $\mathbf{R 2}$ & $\mathbf{R 3}$ \\
\hline $\begin{array}{c}\text { Support material } \\
\begin{array}{c}\text { Support material } \\
\text { mass }(\mathrm{g})\end{array}\end{array}$ & $\begin{array}{c}\text { Aluminum smashed } \\
\text { capsules }\end{array}$ & $\begin{array}{c}\text { Plastic smashed } \\
\text { capsules and discs }\end{array}$ & $\begin{array}{c}\text { Plastic capsules and } \\
\text { discs }\end{array}$ \\
$\begin{array}{c}\text { Apparent specific } \\
\text { mass }\left(\mathrm{g} \mathrm{cm}^{-3}\right)\end{array}$ & 170 & 120 & 120 \\
& 0.5 & 0.55 & 0.69
\end{tabular}




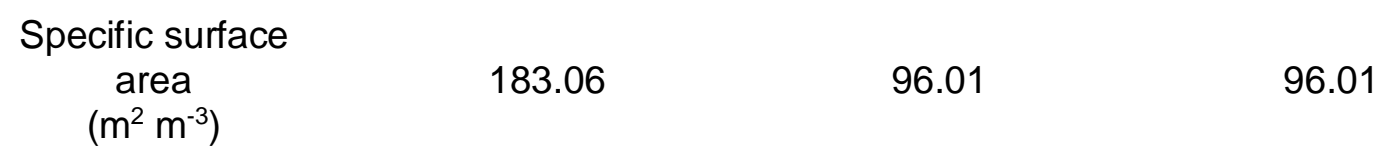

Empty volume (\%) 92 95 96

Influent and effluent samples were collected twice a week to evaluate the reactors performance. The concentration of total solids (TS), total volatile solids (TVS), total suspended solids (TSS), $\mathrm{pH}$ and chemical oxygen demand (COD) were analyzed according to the procedures described in the Standard Methods for the Examination of Water and Wastewater [19]. Bicarbonate alkalinity (BA) and total volatile fatty acid (VFA) were determined according to the method proposed by Dilallo and Albertson [20] and modified by Ripley et al. [21], the ratio between the intermediate and partial alkalinity (IA/PA) was also calculated. All the data were statistically analyzed by non-parametric tests in the software Statistica 10: Mann-Whitney, Kruskal-Wallis and Spearman tests with 5\% significance.

In the end of the experimental period, capsules samples were collected from each reactor to evaluate the biomass attachment. The capsules were washed with distilled water and the biomass detached with a brush. Then, this liquid was examined following the procedures for volatile solids described in the Standard Methods for the Examination of Water and Wastewater [19], in order to quantify the biomass attachment in the support materials. The capsules samples were also taken to the drying oven and their mass was quantified. Therefore, the values of biomass attached were shown per mass of support, that is, how many grams of biomass were attached per mass of support.

The support materials were also examined in a scanning electron microscope (SEM). Samples of the supports were cut and prepared to the visualization in the SEM. The samples were immersed in modified Karnovsky's fixative solution (2.5\% glutaraldehyde and $2.5 \%$ formoldehyde) for a period of at least $24 \mathrm{~h}$. After fixation, the samples were washed three times in a $0.05 \mathrm{M}$ sodium cacodylate buffer for 10 minutes per wash. The samples were then dehydrated in acetone $25,50,75$ and $90 \%$ also for 10 minutes at each concentration and at $100 \%$ for three times for 10 minutes each time. Finally, the samples were fixed upon aluminum supports (stubs), dried up in the Critical Point Dryer Bal Tec CPD 030 and then covered by gold in a Sputter Coater Balzers SCD 050. Afterwards, samples of the support material of each reactor were observed in a scanning electron microscope (LEO EVO 40 Carl Zeiss).

\section{RESULTS}

The reactors performance was evaluated for 137 days and to analyze the results were considered the existence of two operating phases. The first phase occurred from day 1 until day 71, when the WWTP-UFLA was treating only the wastewater originated in the south sewage pumping station, where the sewage from the university buildings and the restaurant is released. After this period, the sewage from the north region of the university, including the effluents from the Veterinary Hospital, started being pumped into the WWTP-UFLA. This caused an increase in the influent COD concentration, and, as consequence, an organic loading rate (OLR) elevation. However, there was no significant difference ( $p>0.05$ ) between the organic matter removal efficiencies in the two delimited operating phases. Despite the increase in the organic load applied, the reactors performances did not change significantly.

\section{Reactors performance}

The average $\mathrm{pH}$ in the reactors was near neutrality, though $\mathrm{R} 3$ has shown an increase in effluent values compared to the influent in both operating phases $(p>0.05)$. The few oscillations in the $\mathrm{pH}$ values during the monitoring period indicated the system buffering capacity and their steadiness. Table 2 shows the mean values of $\mathrm{pH}, \mathrm{BA}, \mathrm{VFA}$ and the ratio IA/PA in both experimental phases. 
Table 2. Mean values of influent and effluent $\mathrm{pH}$ and alkalinity forms.

\begin{tabular}{cccc}
\hline Variable & & Phase I & Phase II \\
\hline & Influent & $7.6 \pm 0.3^{(15)}$ & $7.6 \pm 0.2^{(15)}$ \\
$\mathrm{pH}$ & $\mathrm{R} 1$ & $7.7 \pm 0.4^{(15)}$ & $7.7 \pm 0.1^{(15)}$ \\
& $\mathrm{R} 2$ & $7.7 \pm 0.3^{(15)}$ & $7.7 \pm 0.2^{(15)}$ \\
& $\mathrm{R} 3$ & $7.8 \pm 0.3^{(15)}$ & $7.9 \pm 0.2^{(15)}$ \\
\hline \multirow{3}{*}{$\mathrm{BA}$} & Influent & $176 \pm 39^{(12)}$ & $119 \pm 39^{(14)}$ \\
$\left(\mathrm{mg} \mathrm{L}^{-1}\right.$ of $\left.\mathrm{CaCO}_{3}\right)$ & $\mathrm{R} 1$ & $193 \pm 28^{(12)}$ & $162 \pm 29^{(14)}$ \\
& $\mathrm{R} 2$ & $184 \pm 24^{(12)}$ & $156 \pm 37^{(14)}$ \\
& $\mathrm{R} 3$ & $186 \pm 41^{(12)}$ & $157 \pm 32^{(14)}$ \\
\hline \multirow{2}{*}{ VFA } & Influent & $226 \pm 84^{(12)}$ & $119 \pm 39^{(14)}$ \\
& $\mathrm{R} 1$ & $277 \pm 66^{(12)}$ & $184 \pm 70^{(14)}$ \\
& $\mathrm{R} 2$ & $257 \pm 64^{(12)}$ & $178 \pm 74^{(14)}$ \\
& $\mathrm{R} 3$ & $269 \pm 77^{(12)}$ & $179 \pm 71^{(14)}$ \\
\hline IA/PA & Influent & $0.29 \pm 0.10^{(12)}$ & $0.38 \pm 0.14^{(14)}$ \\
& $\mathrm{R} 1$ & $0.25 \pm 0.07^{(12)}$ & $0.32 \pm 0.09^{(14)}$ \\
& $\mathrm{R} 2$ & $0.27 \pm 0.06^{(12)}$ & $0.32 \pm 0.09^{(14)}$ \\
& $\mathrm{R} 3$ & $0.25 \pm 0.05^{(12)}$ & $0.31 \pm 0.11^{(14)}$ \\
\hline
\end{tabular}

(n) in parenthesis the number of data considered to the mean values.

In Figure 2, it is observed that the IA/PA ratio was higher than 0.30 in most analysis of the second phase of the procedure. However, the steadiness of the anaerobic digestion might occur in values higher than $0.30[22,23]$, thereby there was no significant drop in COD removal efficiencies in the reactors.

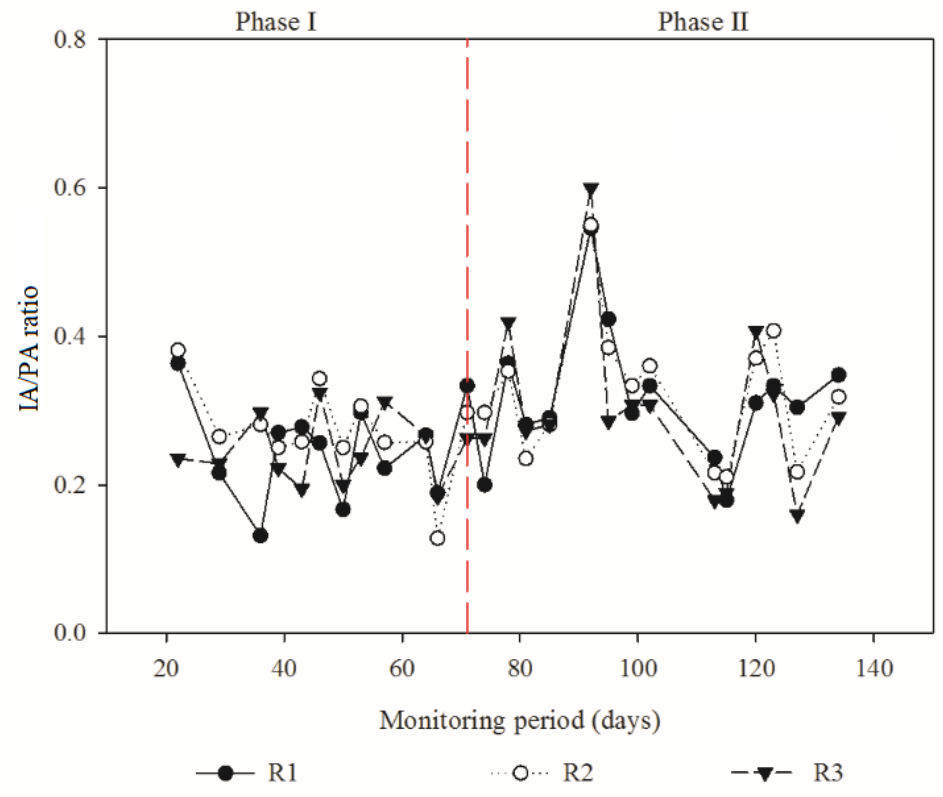

Figure 2. Temporal variation of IA/PA ratio.

The average COD removal efficiencies in $\mathrm{R} 1, \mathrm{R} 2$ and $\mathrm{R} 3$ were similar to those reported by Mockaitis et al. [30] and Fia. et al. [8], who evaluated the efficiency of anaerobic reactors filled with polyurethane foam. In this work the mean OLR in the reactors was 2.1 and $4.0 \mathrm{~kg}$ COD m$~^{-3} \mathrm{~d}^{-1}$, in the first and second phase (Table 3). Figure 3 shows the temporal variation of COD removal efficiencies in relation to the OLR applied to each reactor. 
Table 3. Mean values of OLR and influent and effluent concentrations of COD, TS, TVS, TSS and removal efficiencies.

\begin{tabular}{|c|c|c|c|}
\hline Variable & & Phase I & Phase II \\
\hline \multirow{3}{*}{ 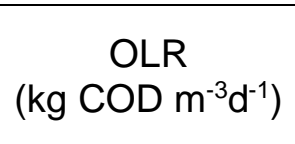 } & $\mathrm{R} 1$ & $2.1 \pm 0.3^{(12)}$ & $3.7 \pm 0.6^{(15)}$ \\
\hline & $\mathrm{R} 2$ & $2.1 \pm 0.3^{(12)}$ & $4.8 \pm 3.2^{(15)}$ \\
\hline & R3 & $2.0 \pm 0.3^{(12)}$ & $3.4 \pm 0.9^{(15)}$ \\
\hline \multirow{4}{*}{$\begin{array}{c}\mathrm{COD} \\
\left(\mathrm{mg} \mathrm{L}^{-1}\right)\end{array}$} & Influent & $889 \pm 134^{(12)}$ & $1458 \pm 229^{(15)}$ \\
\hline & $\mathrm{R} 1$ & $167 \pm 68^{(12)}$ & $205 \pm 71^{(15)}$ \\
\hline & $\mathrm{R} 2$ & $163 \pm 51^{(12)}$ & $219 \pm 92^{(15)}$ \\
\hline & $\mathrm{R} 3$ & $169 \pm 89^{(12)}$ & $211 \pm 80^{(15)}$ \\
\hline \multirow{4}{*}{$\begin{array}{c}\text { TS } \\
\left(\mathrm{mg} \mathrm{L}^{-1}\right)\end{array}$} & Influent & $907 \pm 134^{(13)}$ & $1322 \pm 182^{(15)}$ \\
\hline & $\mathrm{R} 1$ & $417 \pm 56^{(13)}$ & $351 \pm 44^{(15)}$ \\
\hline & $\mathrm{R} 2$ & $460 \pm 114^{(13)}$ & $348 \pm 42^{(15)}$ \\
\hline & R3 & $441 \pm 114^{(13)}$ & $353 \pm 36^{(15)}$ \\
\hline \multirow{4}{*}{$\begin{array}{c}\text { TVS } \\
\left(\mathrm{mg} \mathrm{L}^{-1}\right)\end{array}$} & Influent & $435 \pm 108^{(13)}$ & $704 \pm 130^{(15)}$ \\
\hline & $\mathrm{R} 1$ & $113 \pm 59^{(13)}$ & $103 \pm 54^{(15)}$ \\
\hline & $\mathrm{R} 2$ & $157 \pm 111^{(13)}$ & $107 \pm 56^{(15)}$ \\
\hline & R3 & $144 \pm 123^{(13)}$ & $106 \pm 52^{(15)}$ \\
\hline \multirow{4}{*}{$\begin{array}{c}\text { TSS } \\
\left(\mathrm{mg} \mathrm{L}^{-1}\right)\end{array}$} & Influent & $413 \pm 93^{(8)}$ & $839 \pm 167^{(7)}$ \\
\hline & $\mathrm{R} 1$ & $22 \pm 10^{(8)}$ & $26 \pm 10^{(7)}$ \\
\hline & $\mathrm{R} 2$ & $29 \pm 19^{(8)}$ & $27 \pm 11^{(7)}$ \\
\hline & R3 & $15 \pm 10^{(8)}$ & $26 \pm 10^{(7)}$ \\
\hline \multirow{3}{*}{$\begin{array}{c}\text { COD removal } \\
(\%)\end{array}$} & $\mathrm{R} 1$ & $81.0 \pm 7.0^{(12)}$ & $85.0 \pm 5.0^{(15)}$ \\
\hline & $\mathrm{R} 2$ & $81.0 \pm 6.0^{(12)}$ & $85.0 \pm 6.0^{(15)}$ \\
\hline & R3 & $81.0 \pm 9.0^{(12)}$ & $85.0 \pm 6.0^{(15)}$ \\
\hline \multirow{3}{*}{$\begin{array}{c}\text { TS removal } \\
(\%)\end{array}$} & $\mathrm{R} 1$ & $53.0 \pm 8.0^{(13)}$ & $73.0 \pm 5.0^{(15)}$ \\
\hline & $\mathrm{R} 2$ & $48.0 \pm 15.0^{(13)}$ & $73.0 \pm 5.0^{(15)}$ \\
\hline & R3 & $51.0 \pm 12.0^{(13)}$ & $73.0 \pm 4.0^{(15)}$ \\
\hline \multirow{3}{*}{$\begin{array}{c}\text { TVS removal } \\
(\%)\end{array}$} & R1 & $74.0 \pm 12.0^{(13)}$ & $85.0 \pm 7.0^{(15)}$ \\
\hline & $\mathrm{R} 2$ & $64.0 \pm 27.0^{(13)}$ & $85.0 \pm 8.0^{(15)}$ \\
\hline & R3 & $69.0 \pm 22.0^{(13)}$ & $85.0 \pm 7.0^{(15)}$ \\
\hline \multirow{3}{*}{$\begin{array}{c}\text { TSS removal } \\
(\%)\end{array}$} & $\mathrm{R} 1$ & $94.0 \pm 3.0^{(8)}$ & $93.0 \pm 3.0^{(7)}$ \\
\hline & $\mathrm{R} 2$ & $92.0 \pm 6.0^{(8)}$ & $93.0 \pm 3.0^{(7)}$ \\
\hline & R3 & $96.0 \pm 4.0^{(8)}$ & $93.0 \pm 3.0^{(7)}$ \\
\hline
\end{tabular}

(n) in parenthesis the number of data considered to the mean values. 

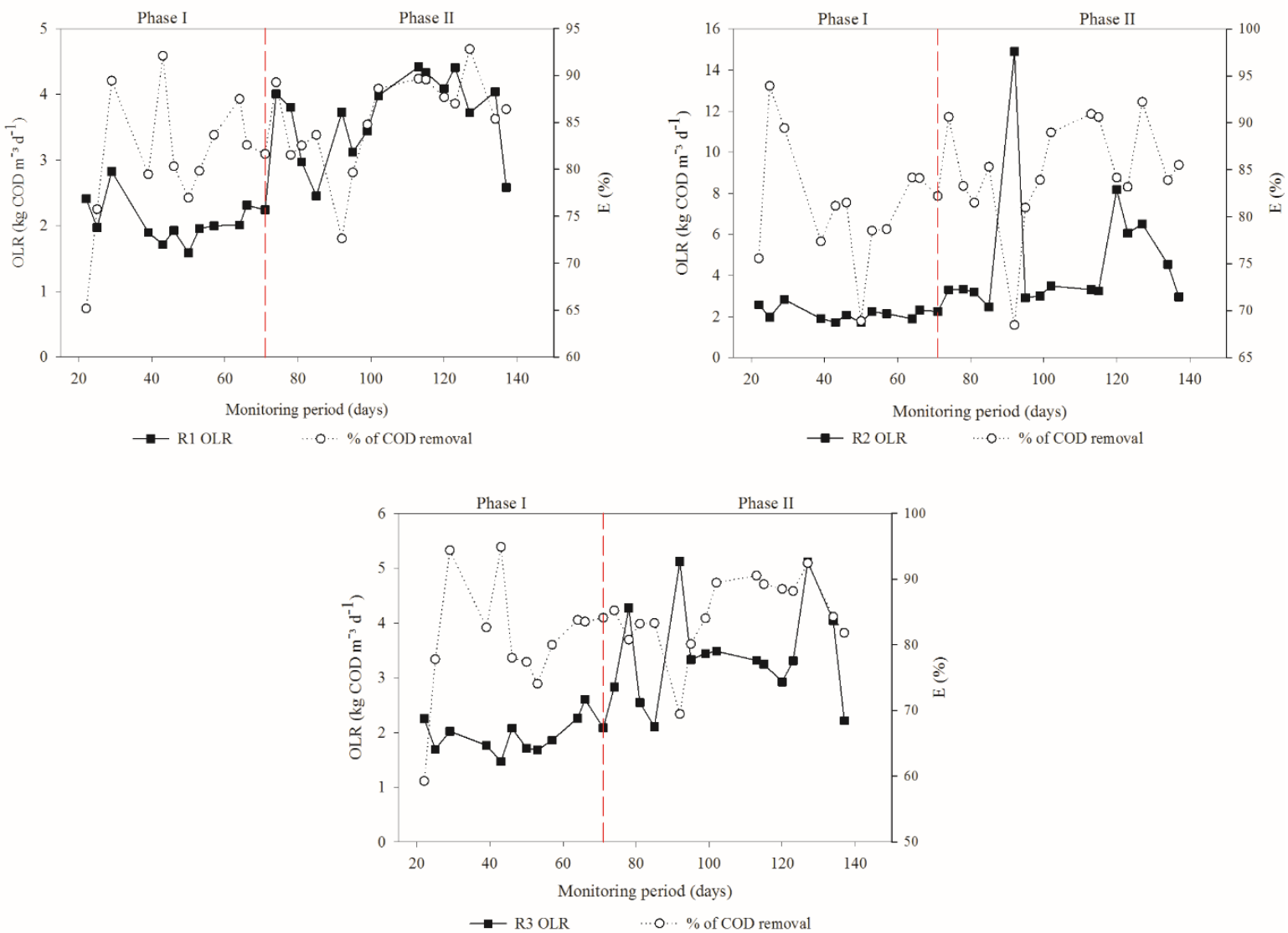

Figure 3. Temporal variation of COD removal efficiencies in relation to the OLR applied to each reactor.

\section{Biomass attachment}

Table 4 presents the biomass attachment in three different perspectives, per mass of support in each reactor, per volume of the reactor and the total mass attached. R2 and R3 differ in the support material only in that the plastic capsules have been smashed in R2. Based on the attached solid values, it is observed that using smashed capsules was efficient, considering that R2 presented biomass attachment of total solids 2.0 times higher and volatile solids 1.7 time higher than R3. The use of smashed aluminum capsules in R1 was also an efficient strategy to biomass attachment, due to the material low roughness. This support material presented higher values of total and volatile attached solids. The specific surface area in the reactor filled with aluminum capsules (R1) was the highest $\left(183.06 \mathrm{~m}^{2}\right.$ $\mathrm{m}^{-3}$ ), which contributed considerably to the greater biomass attachment.

Table 4. Mean concentration of biofilm attached per mass of support and per reactor volume, and total attached biomass in each reactor.

\begin{tabular}{ccccccc}
\hline & \multicolumn{2}{c}{ Total Attached Solids } & \multicolumn{2}{c}{ Total Volatile Attached Solids } \\
\cline { 2 - 7 } Reactor & $\begin{array}{c}\text { per mass } \\
\text { of support } \\
\left(\mathbf{m g ~ g}^{-1}\right)\end{array}$ & $\begin{array}{c}\text { per } \\
\text { reactor } \\
\text { volume } \\
\left(\mathbf{g ~ L}^{-1}\right)\end{array}$ & $\begin{array}{c}\text { total } \\
\text { biomass } \\
(\mathbf{g})\end{array}$ & $\begin{array}{c}\text { per mass } \\
\text { of support } \\
\left(\mathbf{m g ~ g}^{-1}\right)\end{array}$ & $\begin{array}{c}\text { per } \\
\text { reactor } \\
\text { volume } \\
\left(\mathbf{g ~ L}^{-1}\right)\end{array}$ & $\begin{array}{c}\text { total } \\
\text { biomass } \\
(\mathbf{g})\end{array}$ \\
\hline R1 & 40.5 & 1.6 & 6.9 & 12.4 & 0.5 & 2.1 \\
R2 & 36.9 & 1.0 & 4.4 & 12.6 & 0.3 & 1.5 \\
R3 & 18.5 & 0.5 & 2.2 & 7.5 & 0.2 & 0.9 \\
\hline
\end{tabular}


In Figure 4, it is possible to observe a satisfactory microorganism attachment to the capsules, mainly in R1, which showed better attachment in the SEM observations. R3 presented less attachment, meaning that the strategy of using smashed capsules was effective to increase microorganism attachment. The plastic discs also presented good levels of attachments, as it can be observed in Figure $4 \mathrm{~d}$.

a)

b)

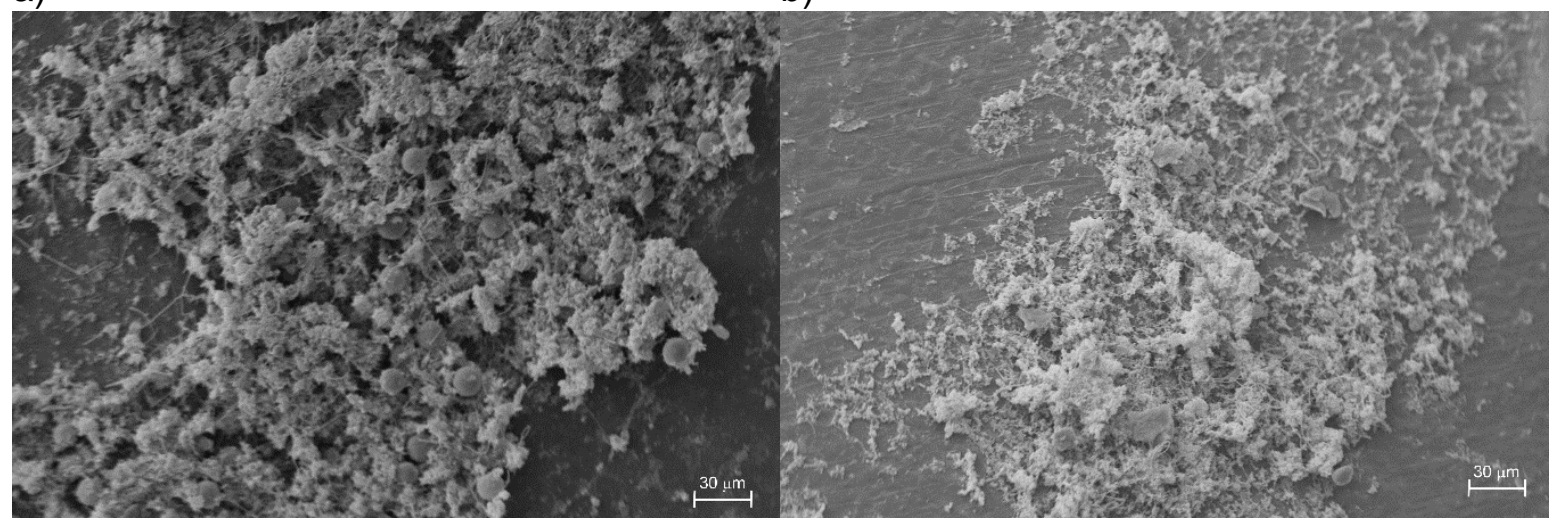

c)

d)

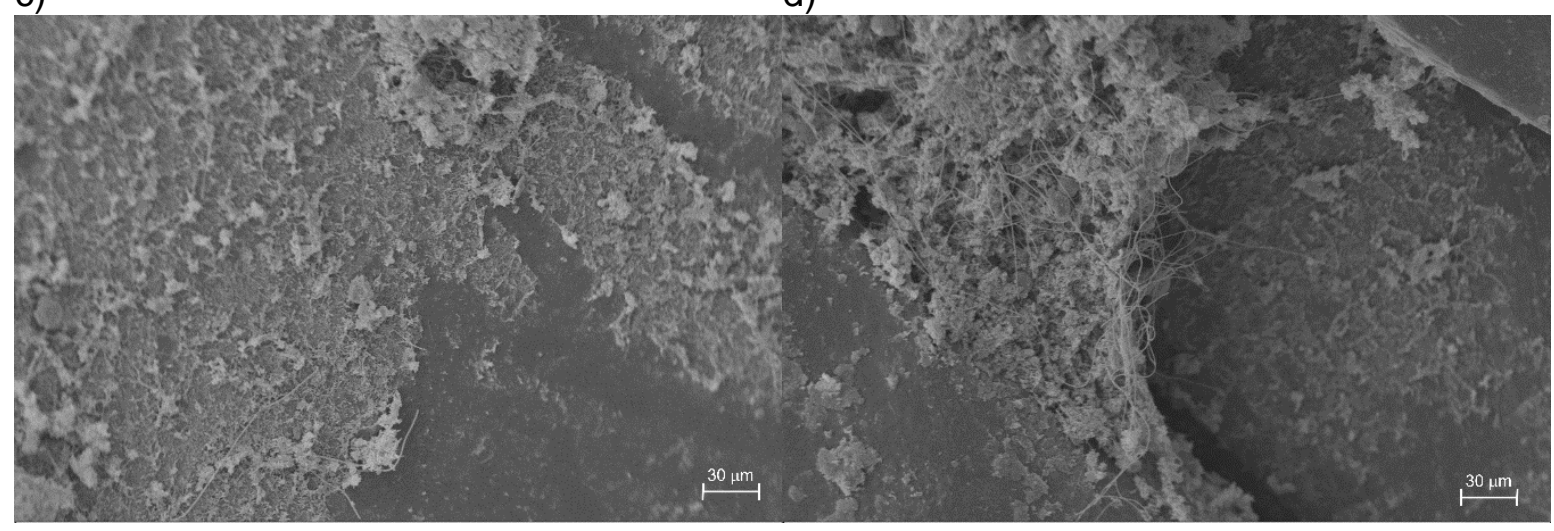

Figure 4. Biomass attachment in (a) aluminum capsule at R1; (b) smashed plastic capsule at R2; (c) plastic capsule at R3 and (d) plastic discs in a zoom of 600x.

The morphologies in the biofilm could be observed in a zoom of 4000x and 7000x (Fig. $5)$. In all the reactors were observed morphologies of cocci and bacilli forming a variety of arrangements. These morphologies suggest the presence of acetoclastic methanogens of Methanosarcina sp. and Methanosaeta sp. Filamentous bacteria, which compose the microbial biofilm structure. In Figure 5a, it can be seen morphologies of sarcine, cocci and bacilli, as well as filamentous bacteria and extracellular polymers. The morphologies of short bacilli, characteristic of Methanobrevibacter sp., are shown in Figure 5b. Furthermore, in Figure $5 \mathrm{c}$ and $5 \mathrm{e}$ spirals morphologies are observed, which is a characteristic of Methanospirillum sp., indicating the presence of hydrogenotrophic methanogenic archaea. 
a)

b)

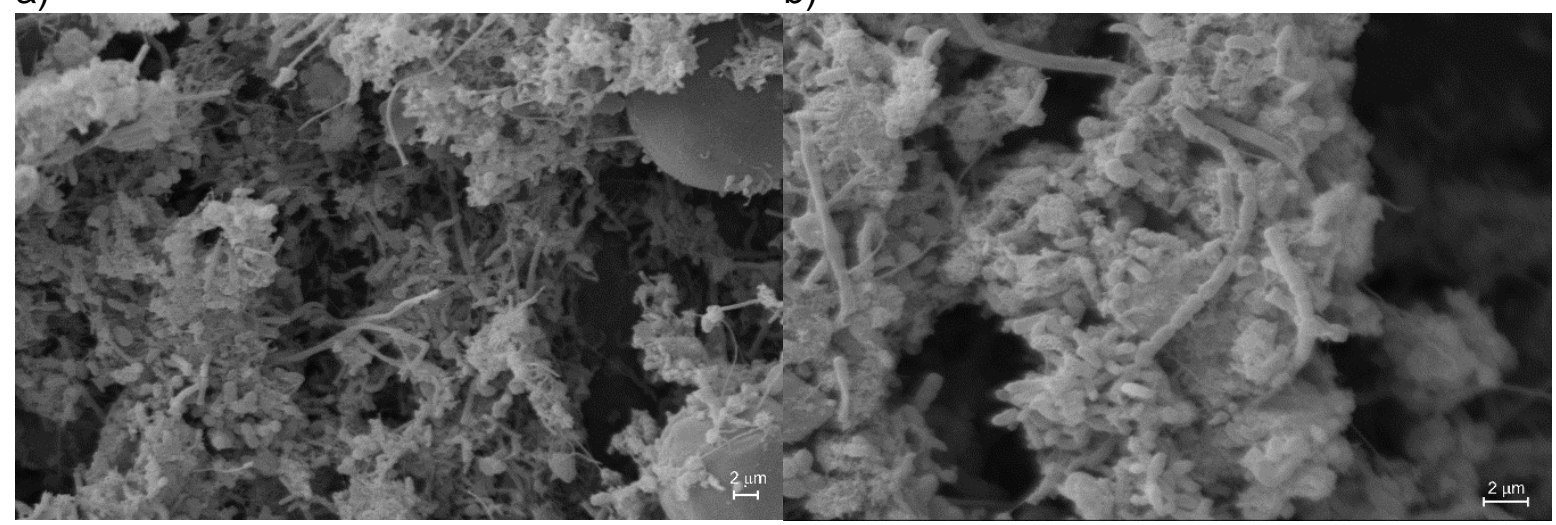

c)

d)

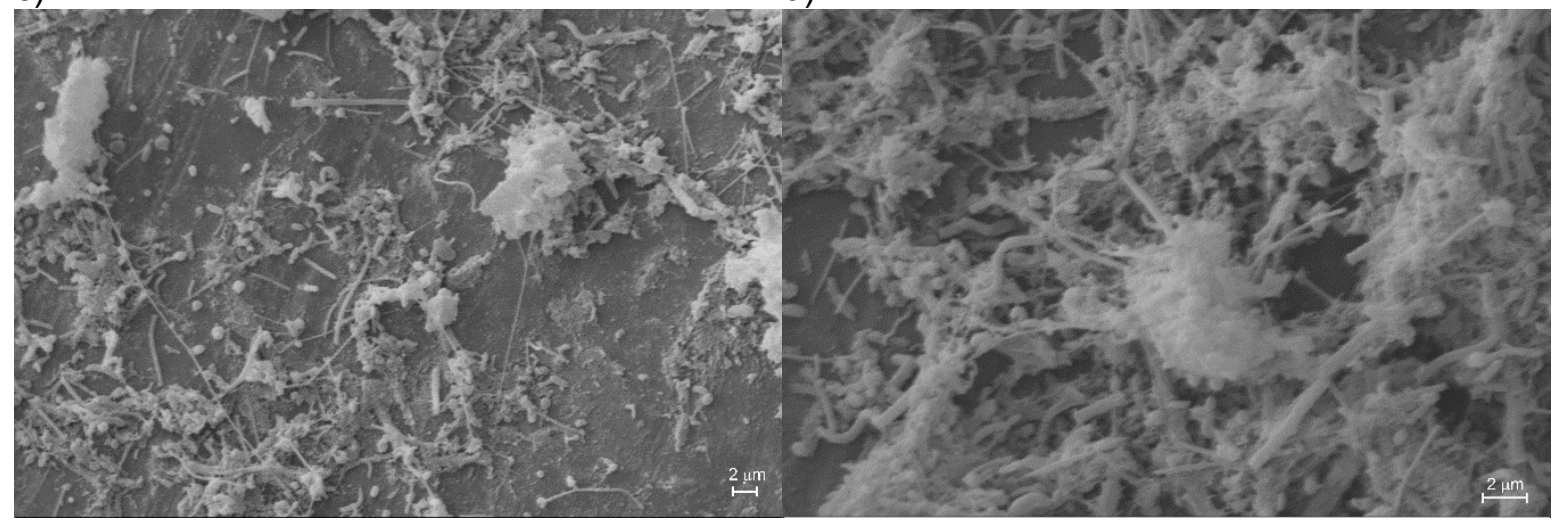

e)

f)

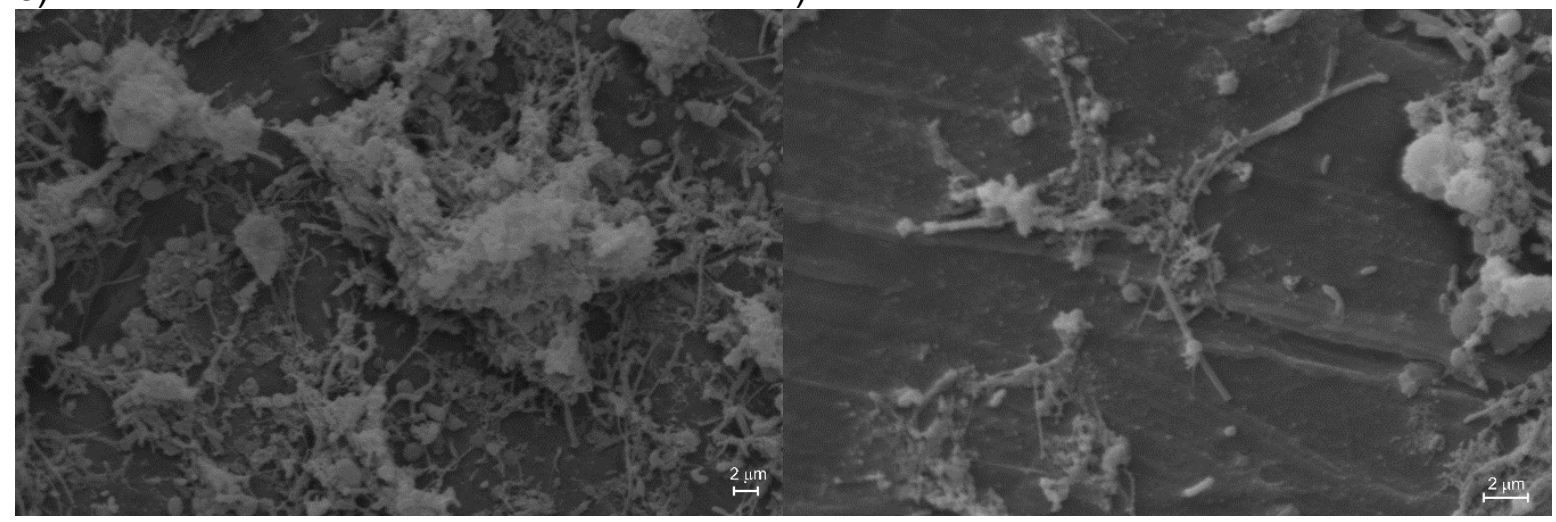

Figure 5. Biomass attachment and morphologies showed up in R1 at (a) 4000x and (b) $7000 x$; in $R 2$ at (c) 4000x and (d) 7000x and in R3 at (e) 4000x and (f) 7000x.

\section{DISCUSSION}

According to Table 2, BA and VFA concentrations were statistically lower in the second phase, when the influent COD increased, consequently increasing the reactors OLR. This was caused by the addition of the new influent in the system from the Veterinary Hospital of UFLA. According to Fialho [25], the wastewater from the veterinary pumping station presents a COD/BOD ratio of 3.89 , demonstrating its low biodegradability and the influence of the chemicals used in the hospital in the higher COD values. In this case, when the system is exposed to changes in operating conditions, an OLR increase might cause greater vulnerability, justifying the lower BA and VFA values in this phase. Nonetheless, even with low $B A$ values, the reactors maintained adequate performance in the second operating phase. VFA concentrations did not differ statistically $(p>0.05)$ between influent and effluent, contrary to Fernandes and Oliveira [26] and Foco and Nour [27]. According to these authors, 
the concentration of VFA decreased comparing to the influent, indicating the buffering capacity of the system.

Fia et al. [8] verified an increase in the concentration of VFA as the OLR increased in anaerobic filters that were used in the treatment of coffee wastewater. Nevertheless, this difference was not observed in the reactors filled with capsules, since the VFA values were lower in the phase with higher OLR.

According to Zhao and Kugel [28] the reactors buffering capacity reduces in IA/PA values between 0.40 and 0.80 , being nonexistent above this limit. Even in the second phase, when IA/PA values were higher, the buffering capacity was not inhibited in none of the reactors, since the ratio remained below 0.80 . Pereira et al. [29] verified IA/PA values above 0.50 during the operation of an UASB reactor treating swine wastewater. These authors evidenced that despite the high ratio presented by the reactor operating at an OLR of $59 \mathrm{~kg}$

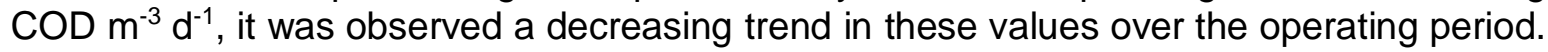
This fact indicated biomass acclimatization and good performance of the anaerobic digestion process.

A low IA/PA ratio indicates that there is a higher concentration of bicarbonate alkalinity compared to total volatile acids. This demonstrates the system ability to neutralize the acids produced during the hydrolysis. Thus, the anaerobic digestion process takes place more steadily, favoring methane production and increasing the efficiency of organic matter removal, since the methanogenic archaea has an optimal growth range at $\mathrm{pH}$ ranging from 6.6 to 7.4 [22, 30]. Spearman's test, with $5.0 \%$ significance, showed that there is no significant correlation between the COD removal and the IA/PA ratio in the first operating phase. However, in the second phase, $\mathrm{R} 1$ and $\mathrm{R} 2$ presented a negative correlation between these variables. In other words, with a decrease of the IA/PA ratio there was an increase in the reactors COD removal efficiencies.

Fia et al. [8] worked with coffee bean processing wastewater treated in an anaerobic filter at an OLR of $4.41 \mathrm{~kg}$ COD m-3 d-1 and reported a removal efficiency of organic matter of $80.0 \%$. This OLR value were close to those applied to the reactors in the second phase of operation, which presented COD removal efficiencies average of $85.0 \pm 5.0 \%$ in $R 1$, $85.0 \pm 6.0 \%$ in $\mathrm{R} 2$ and $85.0 \pm 6.0 \%$ in $\mathrm{R} 3$.

López-López et al. [31] used a volcanic rock, called Tezontle, to support biomass immobilization in an upflow anaerobic filter with $65.0 \%$ porosity. The authors observed that the influence of temperature was the most important factor in increasing the removal of organic matter. In their work, the COD removal efficiency increased from $57.0 \%$ at $20.0^{\circ} \mathrm{C}$ to $85.7 \%$ at $35.0^{\circ} \mathrm{C}$, working in an HRT of $24 \mathrm{~h}$. In the present work, the reactors were operated at ambient temperature, which directly influenced their performance. Nevertheless, even at temperatures near to $20.0^{\circ} \mathrm{C}$, the reactors presented average COD removal efficiencies higher than those verified by López-López et al. [31], such as the value of $59.9 \%$ reached at $20.0^{\circ} \mathrm{C}$, an HRT of $12 \mathrm{~h}$ and influent COD of $475.2 \mathrm{mg} \mathrm{L}^{-1}$.

The TS, TVS and TSS removal efficiencies presented variations along the monitoring period. At the startup period, solid loss occurred in the systems which resulted in lower COD removal efficiencies. This fact also influenced the performance at the beginning of the second operating phase. In this phase, there was a sudden increase in the OLR and lower COD removal efficiencies due to the low amount of biomass present in the reactors. Statistically, the TS and TVS removal was higher in the second phase $(p<0.05)$ and remained steady. This indicated the greater stability of the units, even with OLR variations. In both phases, there was no significant difference in the removal efficiencies between the reactors $(p>0.05)$.

Table 3 shows that despite the significant increase in the TSS influent concentration from the first to the second phase of operation $(p<0.05)$, the reactors maintained satisfactory performance, and there was no significant difference in effluent concentrations among R1, R2 and R3. The same occurred with the removal efficiencies between the two phases and between the reactors ( $p>0.05$ ), showing high TSS removal efficiencies. Although the biomass inside the reactors has not been evaluated between phases, these 
results may indicate the presence of a satisfactory microbial community already in the first phase, once the reactors removal efficiencies remained steady in the second phase.

The organic matter degradation in anaerobic filters is directly related to the removal of suspended solids. In these reactors, the sewage treatment occurs mainly by physical processes of pollutants removal. Therefore, the high removal efficiencies of TSS contributed to the reactors efficiency in COD removal. Tonon et al. [32] verified a COD removal average of $65.0 \pm 15.0 \%$ and effluent TSS concentration of $62.0 \pm 24.0 \mathrm{mg} \mathrm{L}^{-1}$ in the treatment of domestic sewage using anaerobic filters filled with coconut shells, at an influent COD average of $982.0 \pm 424.0 \mathrm{mg} \mathrm{L}^{-1}$.

The use of plastic residues as support for biomass immobilization is an excellent alternative to material reuse. This alternative reduces the amount of residue produced and the energy expenditure in the production of new support materials [33]. Giustina et al. [34] used PET bottles caps and bottlenecks as support in a three-stage submerged aerated biofilter (SAF) to treat domestic sewage. Despite the differences between aerobic and anaerobic biofilm attachment and microorganism metabolism, the authors reported satisfactory microbial attachment to the support used and COD removal values above $90 \%$. Martí-Herrero et al. [35] operated a tubular digester filled with PET rings, cut from soda bottles, to treat cow manure at an OLR of $0.264 \mathrm{Kg} \mathrm{VS} \mathrm{m}^{-3} \mathrm{~d}^{-1}$ and HRT of 80.9 days. These authors reported that, by using PET rings, the functional surface area increases in a 4.1 ratio, increasing the biogas production and consequently the organic matter removal.

Regarding the biomass attachment, Silva et al. [36] verified that porous material were more favorable to biological attachment, therefore, it is feasible to consider that smashing the capsules created more space to bacteria growth. The amount of attached biomass using coffee capsules was higher than when polyethylene was used as support material. Polyethylene presented concentrations of $8.5 \mathrm{mgL}^{-1}$ of total solids and $6.5 \mathrm{mgL}^{-1}$ of volatile solids, and consequent COD removal efficiency of only $33.0 \%$. When using coffee capsules, the lower attachment level of total solids and volatile solids was respectively $500 \mathrm{mgL}^{-1}$ and $200 \mathrm{mgL}^{-1}$ in R3. This happened because polyethylene did not present favorable characteristics to the attachment of the microorganisms, like porosity, for example [4].

Nevertheless, the attachment was lower than using polyurethane foam as support. Mockaitis et al. [24] verified a concentration of $12200 \mathrm{mgL}^{-1}$ of volatile solids, which resulted in COD removal of $78.0 \%$. Abreu and Zaiat [37] verified an attachment of $3350 \mathrm{mgL}^{-1}$ of volatile solids, with a COD removal of $64.0 \%$. Although the differences of biofilm amount in the reactors, they all presented satisfactory performance in organic matter removal, as well as reported by Fia et al. [38], when compared to slag, foam and crashed stone.

Habouzit et al. [39] evaluated microbial attachment in polyethylene (PE), polypropylene (PP), polyvinyl chloride (PVC), acrylonitrile butadiene styrene (ABS), polycarbonate (PC), borosilicate glass and stainless steel. Microscopic observations made by the authors evidenced different percentages of attachment between the support materials used. Stainless steel presented higher percentage of attachment than PE and smaller than PP, polymers that are possibly a component of the plastic capsules used in this work. According to the authors, materials with lower surface energy values benefit the attachment of the microorganisms. In their study, the stainless steel presented lower surface energy than the plastic materials and greater amount of anaerobic microorganisms attached to the surface [39]. This explains the highest attachment capacity observed when using aluminum capsules, which have a similar surface as stainless steel, compared to the plastic ones.

The diversity of microorganisms attached to the support materials observed in this work indicates the good ecological balance that benefits organic matter degradation. Likewise it indicates that there was not endogenia conditions and the loading rate applied was enough to the microorganisms metabolism [36].

The presence of extracellular polymers in all reactors demonstrates the microorganisms' ability to attach to the surface of the capsules. Moreover, it was a strategy for survival of these microorganisms, taking into consideration that the system operating conditions were not favorable [40]. As reported by Pereira et al. [29], morphologies similar to Methanosarcina 
sp. were predominant compared to the presence of Methanosaeta sp., which can be explained by the high concentrations of VFA in the reactors.

Nguyen et al. [40] evaluated the initial biofilm formation and the attachment of Methanosarcina barkeri to polymeric materials. The support materials used were polyethylene (PE), polypropylene (PP), polyvinyl chloride (PVC), polyvinylidene fluoride (PVDF), polyethylene terephthalate (PETG) and polytetrafluoroethylene (PTFE). The PVC showed better initial attachment among the materials. In addition, there was no difference in the initial attachment among the PTGE, PVDF and PE substrates, which presented less surface area covered by the archaea and also presented poor biofilm formation. The authors emphasize the importance of knowing the characteristics of the materials that cover the area. This is important since the attachment of $M$. barkeri was strongly influenced by the type of material used as support. Habouzit et al. [39] also reported that PVC had better affinity with archaea and consequently better performance in anaerobic digestion. This fact can explain the good performance of $\mathrm{R} 2$, which presented satisfactory organic matter removal efficiencies, even though it had undergone wider variations in the operating conditions.

\section{CONCLUSION}

The reactors presented satisfactory performance in the sanitary sewage treatment, reaching efficiencies of organic matter removal higher than $80 \%$. They also presented relative steadiness, even when operating at low ambient temperature and suffering considerable oscillations in the organic load applied. However, the low values of bicarbonate alkalinity and high values of total volatile acids, as well as high IA/PA ratio verified in the reactors, indicate that they did not reach adequate stability in the monitored period.

The coffee capsules used as support material in anaerobic reactors have similar characteristics compared to carrier materials that have commercial and research use. The use of smashed capsules provided a better retention of the microorganisms, besides preventing the link of the support material inside the reactor. Moreover, since the aluminum and plastic capsules have shown no considerable difference in performance, it is possible that both materials can be used together to fill reactors.

Hence, the reuse of the capsules as a support material in the treatment of sewage is an alternative to the destination of this waste. However, its viability for large-scale use would only be possible with a suitable separation of the capsules by the users and an effective segregation and collection by the authorities responsible for the waste management.

Acknowledgments: The authors acknowledge CAPES (Coordenação de Aperfeiçoamento de Pessoal de Nível Superior) (Brazil) for the fellowship grant and financial support of this work. As well the Federal University of Lavras due to the work support.

Conflicts of Interest: The authors declare no conflict of interest

\section{REFERENCES}

1. Agência Nacional de Águas (ANA). Conjuntura dos recursos hídricos no Brasil 2017: relatório pleno. Brasilia, BR: 2017.

2. Agência Nacional de Águas (ANA). Atlas Esgotos: despoluição de bacias hidrográficas. In: Ambiental SNdS, editor. 2017. p. 88.

3. Young JC, McCarty PL. The anaerobic filter for waste treatment. J Water Pollut Control Fed 1969, R160-R73.

4. Garcia M, Lapa K, Foresti E, Zaiat M. Effects of bed materials on the performance of an anaerobic sequencing batch biofilm reactor treating domestic sewage. J. Environ. Manage. 2008, 88(4),1471-7.

5. Yu Y, Feng Y, Quu L, Han W, Guan L. Effect of grain-slag media for the treatment of wastewater in a biological aerated filter. Bioresour. Technol. 2008, 99(10), 4120-3.

6. Wolff DB, Paul E, Costa RHRd. Influência do tipo de material suporte no desempenho de reatores biológicos de leito móvel na remoção de carbono e nitrificação de esgoto sanitário. Eng Sanit Ambient 2010, 15(2),149-54. 
7. Almeida PGSd, Oliveira SC, Chernicharo CAdL. Operation of trickling filters post-UASB reactors without the secondary sedimentation stage. Eng Sanit Ambient 2011, 16(3), 281-90.

8. Fia FR, Matos AT, Borges AC, Fia R, Cecon PR. Treatment of wastewater from coffee bean processing in anaerobic fixed bed reactors with different support materials: performance and kinetic modeling. J. Environ. Manage. 2012, 108, 14-21.

9. $\mathrm{Hu} Z$, Gagnon GA. Impact of filter media on the performance of full-scale recirculating biofilters for treating multi-residential wastewater. Water Res. 2006, 40(7), 1474-80.

10. Camargo SA, Nour EA. Bamboo as an anaerobic medium: effect of filter column height. Water Sci. Technol. 2001, 44(4), 63.

11. Duda RM, Oliveira RAd. Tratamento de águas residuárias de suinocultura em reator UASB e filtro anaeróbio em série seguidos de filtro biológico percolador. Eng. Sanit. Ambient. 2011, 91 100.

12. Tonetti AL, Coraucci Filho B, Guimarães JR, Cruz LMdO, Nakamura MS. Avaliação da partida e operação de filtros anaeróbios tendo bambu como material de recheio. Eng. Sanit. Ambient. 2011.

13. de Oliveira Cruz LM, Stefanutti R, Coraucci Filho B, Tonetti AL. Coconut shells as filling material for anaerobic filters. SpringerPlus. 2013, 2(1), 655.

14. Magri ME, Zaguini JG, Ramos SRA, Philippi LS. Otimização do processo de nitrificação com o uso de conchas de ostras como material suporte em reatores aeróbios com biomassa fixa. Eng. Sanit. Ambient. 2013, 18(2), 123-30.

15. Oliveira RAd, Bruno N. Start-up of horizontal anaerobic reactors with sludge blanket and fixed bed for wastewater treatment from coffee processing by wet method. Eng. Agrí. 2013, 33(2), 353-66.

16. Mergulhão AD. Os fluxos, as relações e os agentes envolvidos na produção e comercialização do café produzido atualmente no Brasil. Anpege. 2017, 13(22), 57-85.

17. Silva EC, da Silva Azevedo A, Junior LGC. MEDIDAS SUSTENTÁVEIS NO MERCADO DE CAFÉ EM DOSE ÚNICA. e-xacta. 2017, 10(2), 57-71.

18. Café BdICd. RELATÓRIO INTERNACIONAL DE TENDÊNCIAS DO CAFÉ. Lavras: 2017 sep 30. Report No.: Contract No.: 8.

19. Association A-APH. AWWA-American Water Works Association \& WEF-Water Environment Federation. Standart methods for the examination of water and wastewater. 1998;20.

20. DiLallo R, Albertson OE. Volatile acids by direct titration. J. Water Pollut. Control Fed. 1961, 35665.

21. Ripley L, Boyle W, Converse J. Improved alkalimetric monitoring for anaerobic digestion of highstrength wastes. J. Water Pollut. Control Fed. 1986, 406-11.

22. Chernicharo CADL. Reatores anaeróbios. 2 ed. Belo Horizonte: Editora UFMG; 2016. 379 p.

23. Foresti E, Florêncio L, Van Haandel A, Zaiat M, Cavalcanti PFF, editors. Fundamentos do tratamento anaeróbio. Tratamento de esgotos sanitários por processo anaeróbio e disposição controlada no solo Rio de Janeiro: ABES; 1999.

24. Mockaitis G, Pantoja J, Rodrigues J, Foresti E, Zaiat M. Continuous anaerobic bioreactor with a fixed-structure bed (ABFSB) for wastewater treatment with low solids and low applied organic loading content. Bioprocess Biosyst Eng. 2014, 37(7), 1361-8.

25. Fialho DES. Caracterização do esgoto sanitário e avaliação da eficiência da ETE/UFLA na remoção de fármacos e desreguladores endócrinos. Master Dissertation, Universidade Federal de Lavras, 2019.

26. Fernandes GF, Oliveira RAd. Desempenho de processo anaeróbio em dois estágios (reator compartimentado seguido de reator UASB) para tratamento de águas residuárias de suinocultura. Eng. Agrí. 2006, 243-56.

27. Foco MLR, Nour EAA. Desempenho de sistema combinado anaeróbio-aeróbio na remoção de nitrogênio no tratamento de esgoto sanitário. Semin., Ciênc. exatas tecnol. 2014, 35(2), 131-8.

28. Zhao Q, Kugel G. Thermophilic/mesophilic digestion of sewage sludge and organic wastes. $J$ Environ Sci Health A. 1996, 31(9), 2211-31. 
29. Pereira EL, Campos CMM, Moterani F. Effects of $\mathrm{pH}$, acidity and alkalinity on the microbiota activity of an anaerobic sludge blanket reactor (UASB) treating pigmanure effluents. Rev. Ambient. Água. 2009, 4(3), 157-68.

30. Motteran F, Pereira EL, Campos CMM. Characterization of an acidification and equalization tank (AET) operating as a primary treatment of swine liquid effluent. Braz Arch Biol Technol. 2013, 56(3), 485-94.

31. López-López A, Albarrán-Rivas MG, Hernández-Mena L, León-Becerril E. An assessment of an anaerobic filter packed with a low-cost material for treating domestic wastewater. Environ Technol. 2013, 34(9), 1151-9.

32. Tonon D, Tonetti AL, Coraucci Filho B, Bueno DAC. Wastewater treatment by anaerobic filter and sand filter: Hydraulic loading rates for removing organic matter, phosphorus, pathogens and nitrogen in tropical countries. Ecol Eng. 2015, 82, 583-9.

33. De Oliveira LD, Motlagh AM, Goel R, de Souza Missagia B, de Abreu Filho BA, Lautenschlager SR. The use of bottle caps as submerged aerated filter medium. CEP 2014, 87020, 900.

34. Della Giustina SV, Miranda LAS, Monteggia LO. Remoção de matéria orgânica e sólidos suspensos por nova configuração de biofiltro aeróbio submerso no pós-tratamento de efluente de reator UASB. Eng Sanit Ambient 2010, 15(3), 257-66.

35. Martí-Herrero J, Alvarez R, Rojas M, Aliaga L, Céspedes R, Carbonell J. Improvement through low cost biofilm carrier in anaerobic tubular digestion in cold climate regions. Bioresour. Technol. 2014, 167, 87-93.

36. Silva VGd, Campos CMM, Pereira EL, Silva JFd. Characterization of the biomass of a hybrid anaerobic reactor (HAR) with two types of support material during the treatment of the coffee wastewater. Braz Arch Biol Technol. 2013, 56(3), 495-504.

37. Abreu SB, Zaiat M. Desempenho de reator anaeróbio-aeróbio de leito fixo no tratamento de esgoto sanitário. Eng Sanit Ambient 2008, 13(2), 181-8.

38. Fia FR, Borges AC, Matos ATd, Duarte I, Fia R, Campos LCd. Development of biofilm in anaerobic reactors treating wastewater from coffee grain processing. Rev. bras. eng. agríc. ambient. 2010, 14(2), 210-7.

39. Habouzit F, Gévaudan G, Hamelin J, Steyer J-P, Bernet N. Influence of support material properties on the potential selection of Archaea during initial adhesion of a methanogenic consortium. Bioresour. Technol. 2011, 102(5), 4054-60.

40. Nguyen V, Karunakaran E, Collins G, Biggs CA. Physicochemical analysis of initial adhesion and biofilm formation of Methanosarcina barkeri on polymer support material. Colloids Surf $B$ Biointerfaces. 2016, 143, 518-25. 